\title{
RESISTANCE TO THE ACTION OF THE ENDOTOXINS OF ENTERIC BACILLI IN MAN ${ }^{1}$
}

\author{
BY HERBERT R. MORGAN 2 \\ (From the Thorndike Memorial Laboratory, Second and Fourth Medical Services [Harvard], \\ Boston City Hospital, and the Department of Medicine, Harvard Medical School, Boston)
}

(Received for publication May 22, 1948)

The somatic or " $O$ " antigens of the gram-negative, enteric bacilli represent the principal toxic and antigenic constituents of these organisms $(1,2)$. Injected intravenously in man in minute amounts, these antigens produce marked physiological reactions consisting of headache, malaise, chills, fever and granulocytopenia (1). Following repeated injections, the severity of the successive reactions declines until the patient may show no reaction to the injections.

In rabbits injection of these toxic somatic antigens produces similar effects. The decreasing severity of the reactions in the rabbits was shown to be independent of circulating antibody for the antigen injected (2). This "resistance" was also active against certain other somatic antigens which are chemically similar but immunologically distinct (3). Because this resistance is independent of the presence of homologous circulating antibody, the term "tolerance" was suggested (1). The results of further observations on the nature of this tolerance in man are presented here.

\section{MATERIALS AND METHODS}

Preparation of antigens. The somatic antigens of Salmonella typhosa and $S$. schottmuelleri were prepared by the technique previously described (2). The phenol extraction technique (4) was used to prepare the material from Shigella dysenteriae. ${ }^{3}$ The stock solutions of antigen were prepared in distilled water and further dilutions made in sterile saline for injection.

Methods of administration. The patients selected for study included three normal subjects (KD, GF, MB), two patients with gonorrheal infections (SW, IF) and two with asymptomatic, serological syphilis (ML, SM).

1 Presented at the Annual Meeting of the American Society for Clinical Investigation, May 3, 1948, Atlantic City, N. J.

2 Senior Fellow in the Medical Sciences of the National Research Council. Present Address: Department of Epidemiology, School of Public Health, University of Michigan, Ann Arbor, Michigan.

3 Obtained through the kindness of Dr. Manson Meads.
The group included four males and three females. Four patients (SW, IF, ML and SM) were receiving treatment with crystalline penicillin G. The injection of antigen in from 0.5 to $1 \mathrm{ml}$. of saline was given into the median basilic vein. Observations of rectal temperature, pulse and respirations were made just before the injection and at hourly intervals thereafter for six hours or until the temperature fell below $100^{\circ} \mathrm{F}$. The febrile reaction is expressed in terms of fever units considering one degree Fahrenheit above $100^{\circ} \mathrm{F}$. for one hour as one unit of fever.

Serological tests. The "O" agglutinin titers of the serum of each patient for $S$. typhosa (typhoid), S. schottmuelleri (paratyphoid B) and Sh. dysenteriae (Shiga) were determined before the antigen was given and at intervals thereafter. This test was used as a measure of the antibody response to the somatic antigen since previous studies had indicated that it was an accurate measure of the presence of specific antibody for the somatic antigen injected in rabbits (2) and man (1).

\section{RESULTS}

Effective dosage and systemic reactions following injection of antigens. Following their intravenous injection in doses ranging from $0.5 \mu \mathrm{g}$. to $2.0 \mu \mathrm{g}$. these somatic antigens induced reactions. Within 40-50 minutes, the patients developed severe, throbbing, frontal headaches, began to feel chilly and then had shaking chills and muscular aches. In some instances, they became nauseated and vomited. The temperature rose, reached a peak in about two to three hours and then fell slowly to normal levels in from six to eight hours. The Shiga antigen appeared to be the most toxic, producing severe reactions in a dosage of $0.5 \mu \mathrm{g}$. while the somatic antigen of $S$. schottmuelleri was somewhat less active. The typhoid somatic antigen was the least active, requiring about $5 \mu \mathrm{g}$. to induce a severe reaction. Typical fever curves obtained in four of the patients following injections of one of the somatic antigens are presented in Figure 1.

Development of tolerance following repeated antigen injections. During the course of consecutive injections of antigen, the response of the pa- 


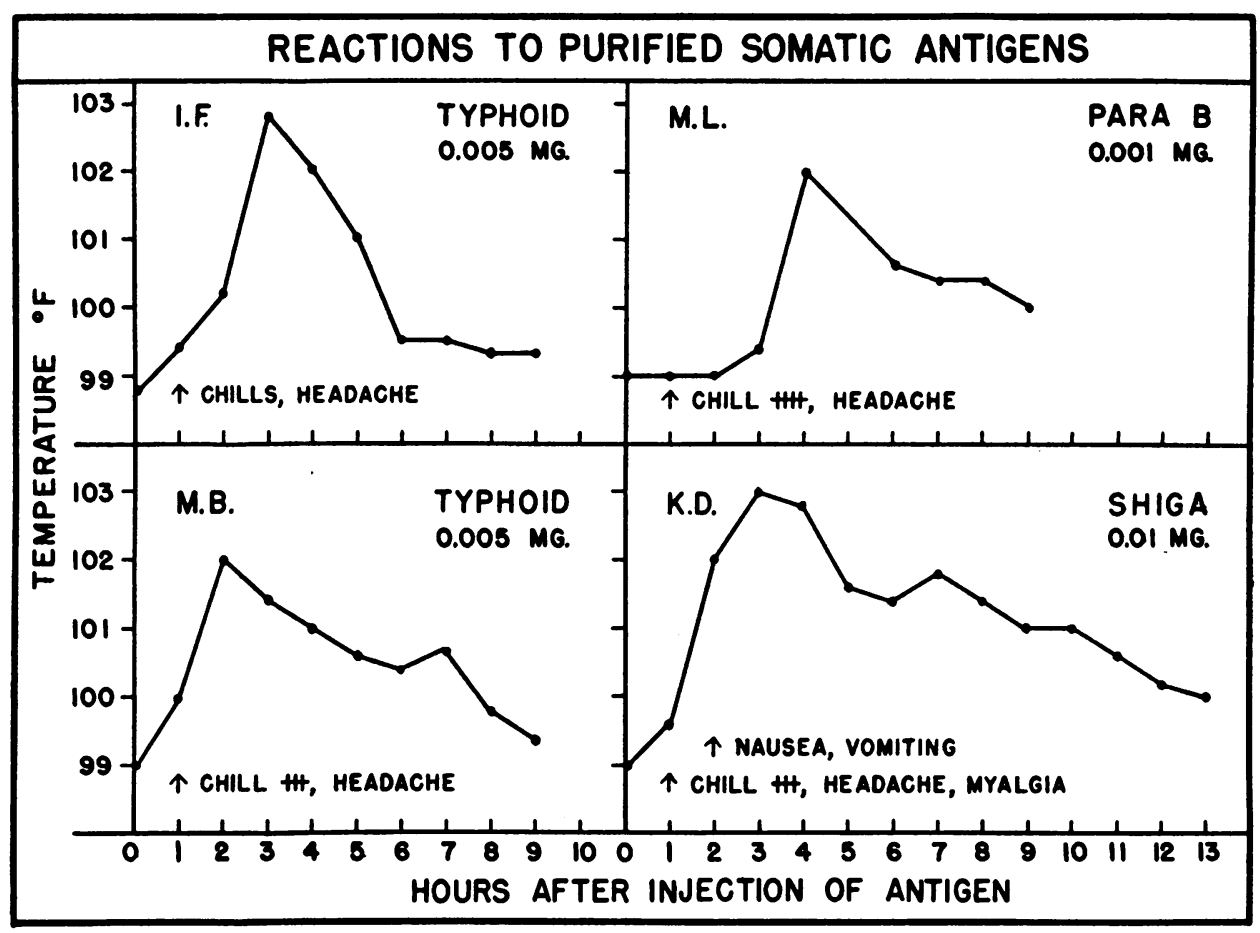

Fig. 1. Effects of Intravenous Injection of Toxic Somatic Antigens of Enteric BaCILLI IN MAN

tients became less marked until they showed no reaction to its administration. Table I presents results of the effects observed in two of the seven patients studied which are representative. In both

TABLE I

Increasing tolerance to injection of toxic somatic antigens

\begin{tabular}{|c|c|c|c|c|}
\hline Patient & Day & $\begin{array}{l}\text { Antigen* } \\
\text { and } \\
\text { dose }\end{array}$ & Fever units & Symptoms $\dagger$ \\
\hline KD & $\begin{array}{l}1 \\
2 \\
3 \\
4 \\
5 \\
6 \\
7 \\
8\end{array}$ & $\begin{array}{r}\text { Mg. } \\
\text { S 0.1 } \\
0.2 \\
0.4 \\
1.0 \\
1.0 \\
1.0 \\
1.0 \\
1.0\end{array}$ & $\begin{array}{r}3.6 \\
4.2 \\
1.5 \\
10.0 \\
1.2 \\
5.6 \\
0.4 \\
0\end{array}$ & $\begin{array}{c}++ \\
+++ \\
\pm \\
++++ \\
++ \\
++ \\
0 \\
0\end{array}$ \\
\hline SW & $\begin{array}{l}1 \\
2 \\
3 \\
4 \\
5 \\
6 \\
7 \\
8\end{array}$ & $\begin{array}{r}\mathrm{T} 1.0 \\
4.0 \\
8.0 \\
20.0 \\
100.0 \\
100.0 \\
100.0 \\
100.0\end{array}$ & $\begin{array}{l}0 \\
1.8 \\
0 \\
0.6 \\
6.6 \\
2.6 \\
0 \\
0\end{array}$ & $\begin{array}{c}0 \\
+ \\
0 \\
\pm \\
++ \\
+ \\
\mathbf{0} \\
0\end{array}$ \\
\hline
\end{tabular}

* $\mathrm{S}=$ Shiga antigen; $\mathrm{T}=$ typhoid antigen.

+ Symptoms: ++++ , severe; +++ , moderate; ++ , mild; + , slight; 0 , none. patients, after several consecutive injections, the reactions became less marked until there was no response to the injection of an amount of antigen which had produced symptoms when first given. Further injections increase the degree of this resistance as seen in the results with patient SW.

Specificity of tolerance produced following injection of a toxic somatic antigen. It was of interest to determine whether the resistant state was effective against antigens other than the one with which the tolerance was produced and whether any observed tolerance to the injection of other antigens could be correlated with the presence of circulating antibodies for these materials. The reactions of the patients to injections of heterologous antigens and the "O".agglutinin titers of their sera are summarized in Table II.

From the data presented in Table II it is apparent that tolerance induced by the injection of either Shiga, typhoid or paratyphoid B antigens is effective not only against the toxic effects of the homologous antigen but also against the heterologous antigens. Injections of similar doses of test antigens at the same time in control patients produced characteristic symptoms and febrile re- 
TABLE II

Heterologous tolerance following injections of toxic somatic antigens

\begin{tabular}{|c|c|c|c|c|c|c|c|}
\hline \multirow[b]{2}{*}{$\begin{array}{c}\text { Pa- } \\
\text { tient }\end{array}$} & \multirow[b]{2}{*}{$\begin{array}{l}\text { Day } \\
\text { in- } \\
\text { jected }\end{array}$} & \multirow[b]{2}{*}{$\begin{array}{l}\text { Antigen* } \\
\text { and } \\
\text { dose }\end{array}$} & \multirow[b]{2}{*}{$\begin{array}{l}\text { Fever } \\
\text { units }\end{array}$} & \multirow[b]{2}{*}{ Symptoms } & \multicolumn{3}{|c|}{ "O" agglutinin titer } \\
\hline & & & & & Typhoid & $\begin{array}{c}\text { Para- } \\
\text { ty- } \\
\text { phoid } \\
\text { B }\end{array}$ & Shiga \\
\hline $\mathrm{KD}$ & $\begin{array}{l}1 \\
4 \\
8 \\
9\end{array}$ & $\begin{array}{l}\mu g . \\
\text { S } 0.1 \\
\text { S } 1.0 \\
\text { S } 1.0 \\
T 6.0\end{array}$ & $\begin{array}{c}3.6 \\
10.0 \\
0 \\
1.4\end{array}$ & $\begin{array}{c}++ \\
+++ \\
0 \\
0\end{array}$ & $\begin{array}{l}<8 \\
<8 \\
<8\end{array}$ & $\begin{array}{l}<8 \\
<8 \\
<8\end{array}$ & $\begin{array}{r}<8 \\
128 \\
128\end{array}$ \\
\hline SW & $\begin{array}{r}1 \\
2 \\
5 \\
10 \\
11 \\
12\end{array}$ & $\begin{array}{r}\mathrm{T} 1.0 \\
\mathrm{~T} 4.0 \\
\mathrm{~T} 100.0 \\
\mathrm{~T} 100.0 \\
\mathrm{~S} 5.0 \\
\mathrm{~B} 10.0\end{array}$ & $\begin{array}{l}0 \\
1.8 \\
6.6 \\
0 \\
0 \\
0\end{array}$ & $\begin{array}{c}0 \\
+ \\
++ \\
0 \\
0 \\
0\end{array}$ & $\begin{array}{l}>2048 \\
>2048\end{array}$ & $\begin{array}{l}2048 \\
1024\end{array}$ & $\begin{array}{l}<8 \\
<8\end{array}$ \\
\hline ML & $\begin{array}{r}1 \\
2 \\
8 \\
9 \\
10\end{array}$ & $\begin{array}{ll}\mathrm{B} & 0.1 \\
\mathrm{~B} & 1.0 \\
\mathrm{~B} & 1.0 \\
\mathrm{~T} & 1.0 \\
\mathrm{~S} & 0.5\end{array}$ & $\begin{array}{l}0 \\
3.2 \\
0 \\
0 \\
1.2\end{array}$ & $\begin{array}{c}0 \\
++ \\
0 \\
0 \\
\pm\end{array}$ & $\begin{array}{l}64 \\
64\end{array}$ & $\begin{array}{l}<8 \\
1024 \\
1024\end{array}$ & $\begin{array}{l}<8 \\
<8 \\
<8\end{array}$ \\
\hline IF $\ddagger$ & $\begin{array}{l}1 \\
2 \\
3\end{array}$ & $\begin{array}{l}\mathrm{T} 1.0 \\
\mathrm{~T} 5.0 \\
\mathrm{~S} 2.0\end{array}$ & $\begin{array}{r}2.4 \\
6.0 \\
10.1\end{array}$ & $\begin{array}{c}++ \\
+++ \\
++++\end{array}$ & $\begin{array}{l}<8 \\
<8\end{array}$ & $\begin{array}{l}<8 \\
<8\end{array}$ & $\begin{array}{l}<8 \\
<8\end{array}$ \\
\hline MB & $\begin{array}{l}1 \\
2 \\
3\end{array}$ & $\begin{array}{l}\mathrm{T} 5.0 \\
\mathrm{~B} 1.0 \\
\mathrm{~S} 0.5\end{array}$ & $\begin{array}{l}6.0 \\
2.8 \\
4.8\end{array}$ & $\begin{array}{c}+++ \\
++ \\
+++\end{array}$ & $\begin{array}{l}<8 \\
<8 \\
<8\end{array}$ & $\begin{array}{l}<8 \\
<8 \\
<8\end{array}$ & $\begin{array}{l}<8 \\
<8 \\
<8\end{array}$ \\
\hline
\end{tabular}

* $\mathrm{S}=$ Shiga antigen; $\mathrm{T}=$ typhoid antigen; $\mathrm{B}=$ paratyphoid $\mathrm{B}$ antigen.

$\dagger$ Expressed as the reciprocal.

$\mp$ Controls.

sponses. Patient KD who developed tolerance following eight consecutive doses of Shiga antigen also developed a resistance to the toxic effects of typhoid antigen. At the time this resistance was active against both Shiga and typhoid antigens, the patient's serum showed "O" agglutinins only for Sh. dysenteriae. Likewise the tolerance developing in patients SW and ML following the administration of typhoid and paratyphoid B antigens, respectively, was shown to protect against the toxic effects of all three antigens in spite of the fact that serum agglutinins were demonstrable only for the organism which possessed the somatic antigen originally injected or an immunologically related antigen. As would be expected, the sera of patients injected with typhoid or paratyphoid $B$ somatic antigens showed agglutinins for both organisms since these organisms possess a common, somatic, antigenic factor.

These data demonstrate that specific circulating antibody is not necessary for the action of this tolerance to the toxic action of purified somatic antigens prepared from $S$. typhosa, S. schottmuelleri or Sh. dysenteriae.

Duration of the tolerant state. Between four to five weeks after the injections of antigens were stopped, patients KD and ML were again found to be susceptible to the toxic effects of the somatic antigens with which they had been injected as demonstrated by the data in Table III.

TABLE III

Duration of the tolerant state induced by injections of somatic antigens

\begin{tabular}{|c|c|c|c|c|c|c|c|}
\hline \multirow{2}{*}{$\begin{array}{c}\mathrm{Pa}- \\
\text { tient }\end{array}$} & \multirow{2}{*}{$\begin{array}{c}\text { Day* } \\
\text { injected }\end{array}$} & \multirow{2}{*}{$\begin{array}{l}\text { Anti- } \\
\text { genf } \\
\text { and } \\
\text { dose }\end{array}$} & \multirow{2}{*}{$\begin{array}{l}\text { Fever } \\
\text { units }\end{array}$} & \multirow[b]{2}{*}{ Symptoms } & \multicolumn{3}{|c|}{ "O" agglutinin titer $\ddagger$} \\
\hline & & & & & $\begin{array}{l}\text { Ty- } \\
\text { phoid }\end{array}$ & $\begin{array}{c}\text { Para- } \\
\text { typhoid } \\
\text { B }\end{array}$ & Shiga \\
\hline $\mathrm{KD}$ & $\begin{array}{r}2 \\
4 \\
8 \\
40\end{array}$ & $\begin{array}{l}\text { sg. } \\
\text { S } 0.2 \\
\text { S } 1.0 \\
\text { S } 1.0 \\
\text { S } 1.0\end{array}$ & $\begin{array}{c}4.2 \\
10.0 \\
0 \\
2.2\end{array}$ & $\begin{array}{c}+++ \\
+++t \\
0 \\
+++\end{array}$ & $\begin{array}{l}<8 \\
<8 \\
<8\end{array}$ & $\begin{array}{l}<8 \\
<8 \\
<8\end{array}$ & $\begin{array}{l}<8 \\
256 \\
256\end{array}$ \\
\hline ML & $\begin{array}{r}3 \\
8 \\
40 \\
114\end{array}$ & $\begin{array}{ll}\mathrm{B} & 1.0 \\
\mathrm{~B} & 1.0 \\
\mathrm{~B} & 1.0 \\
\mathrm{~B} & 1.0\end{array}$ & $\begin{array}{l}3.2 \\
0 \\
2.2 \\
4.2\end{array}$ & $\begin{array}{c}++t \\
0 \\
++ \\
+++\end{array}$ & $\begin{array}{l}<8 \\
64 \\
<8 \\
<8\end{array}$ & $\begin{array}{r}<8 \\
1024 \\
512 \\
256\end{array}$ & $\begin{array}{l}<8 \\
<8 \\
<8 \\
<8\end{array}$ \\
\hline
\end{tabular}

* Injections were given daily for eight days and subsequently only on the days indicated.

$\dagger \mathrm{S}=$ Shiga antigen; $\mathrm{B}=$ paratyphoid $\mathrm{B}$ antigen.

$\ddagger$ Expressed as the reciprocal.

These results indicate that individuals have returned to their original state of susceptibility one month after the injections of antigen are stopped. This loss of tolerance occurs in spite of the persistence of high titers of serum antibody for the antigen injected. These observations give additional evidence for the independence of the tolerant state from this antigen-antibody reaction.

\section{DISCUSSION}

Tolerance to the toxic action of somatic antigens prepared from $S$. typhosa, S. schottmuelleri and $S h$. dysenteriae develops readily in man following repeated intravenous injections of these antigens. Symptoms produced following their injection are commonly encountered as part of the clinical manifestations of infection with these bacteria. Furthermore, in animals, the injection of typhoid somatic antigen produced a type of damage to tissues which shows certain similarities of the 
lesions observed in fatal cases of typhoid fever in man (5). This may indicate that this potent tissue toxin may play a role in the production of changes observed in the organs of patients dying of typhoid fever.

In the case of typhoid fever, evidence has been presented (6) that the somatic antigen may appear in the free state in the blood stream during the early stages of the disease. It is at least strongly suggestive then that the toxic somatic antigens may have an important role in the causation of some of the clinical and pathological aspects of typhoid and paratyphoid fevers and perhaps also in bacillary dysentery. The phenomenon of tolerance to their toxic action is therefore of considerable clinical interest and may be of importance in the natural infections caused by these organisms. Preliminary tests on a patient convalescent from typhoid fever have indicated that this tolerance may develop during the course of the disease and further studies are now in progress to corroborate this observation (7).

The studies presented here and previous reports $(1,2,8)$ indicate that tolerance is not dependent on the presence of specific circulating antibody. The lack of specificity of this resistance with regard to immunological relationships may suggest that some more general function is responsible. Beeson's experiments in rabbits (9) present evidence that this state of resistance is due to an increased activity of the reticulo-endothelial system which removes the pyrogenic materials from the blood stream. So far, no evidence has been presented to show that the tolerance observed in man is due to the same sort of mechanism.

\section{SUM MARY}

1. Following repeated intravenous injections of the somatic antigens prepared from the typhoid bacillus, paratyphoid B bacillus and the Shiga dysentery bacillus in man, tolerance develops to the toxic effects of these antigens as indicated by the failure of the antigens subsequently to produce the characteristic febrile response and constitutional symptoms.

2. Tolerance developing following the administration of any one of these three antigens confers resistance against all three.

3. This resistant state had disappeared in from four to five weeks when the subjects were again tested by injections of these antigens.

4. Tolerance to these somatic antigens does not appear to be related to the presence of circulating antibody for the toxic antigen as measured by the presence of "O" agglutinins.

5. The possible role of this phenomenon in human disease produced by these enteric bacilli is discussed.

\section{BIBLIOGRAPHY}

1. Favorite, G. O., and Morgan, H. R., Effects produced by the intravenous injection in man of a toxic antigenic material derived from Eberthella typhosa: Clinical, hematological, chemical and serological studies. J. Clin. Invest., 1942, 21, 589.

2. Morgan, H. R., Immunologic properties of an antigenic material isolated from Eberthella typhosa. J. Immunol., 1941, 41, 161.

3. Morgan, H. R., Tolerance to the toxic action of somatic antigens of enteric bacteria. J. Immunol., 1948, 59, 129.

4. Palmer, J. W., and Gerlough, T. D., A simple method for preparing antigenic substances from the typhoid bacillus. Science, 1940, 92, 155.

5. Morgan, H. R., Pathologic changes produced in rabbits by a toxic somatic antigen derived from Eberthella typhosa. Am. J. Path., 1943, 19, 135.

6. Dennis, E. W., and Saigh, A. S., Precipitable typhoid somatic antigen in the serum of typhoid fever patients. Science, 1945, 102, 280.

7. Neva, F. A., and Morgan, H. R., Unpublished observations.

8. Beeson, P. B., Tolerance to bacterial pyrogens. I. Factors influencing its development. J. Exper. Med., 1947, 86, 29.

9. Beeson, P. B., Tolerance to bacterial pyrogens. II. Role of the reticulo-endothelial system. J. Exper. Med., 1947, 86, 39. 